\title{
ANTI-OBESITY, SLIMMING, BIOCHEMICAL AND GENOTOXIC EFFECTS OF CORDIA ECALYCULATA IN DIET-INDUCED OBESE RATS
}

\author{
Livia Filla Nunes ${ }^{1}$, Flavia Tasmin Techera Antunes ${ }^{2 \bowtie}$, Alessandra Hubner de Souza ${ }^{2}$, \\ Valesca de Souza Teixeira ${ }^{1}$, Elenir de Fátima Wiilland ${ }^{1}$, Jaqueline Nascimento Picada ${ }^{3}$, \\ Lucimar Filot da Silva Brum ${ }^{1}$
}

${ }^{1}$ Department of Genetics and Applied Toxicology, Lutheran University of Brazil (ULBRA)

Av. Farroupilha, 8001 São José, 92425-900 Canoas, Rio Grande do Sul, Brazil

${ }^{2}$ Postgraduate Program in Cellular and Molecular Biology Applied to Health

Av. Farroupilha, 8001 São José, 92425-900 Canoas, Rio Grande do Sul, Brazil

${ }^{3}$ Laboratory of Genetic Toxicology, Lutheran University of Brazil (ULBRA)

Av. Farroupilha, 8001 São José, 92425-900 Canoas, Rio Grande do Sul, Brazil

\begin{abstract}
Background. Overweight and obesity are associated with deaths and diseases worldwide. Cordia ecalyculata is a plant marketed as a slimmer.

Methods. The study evaluated the anti-obesity effects of the dry extract from C. ecalyculata in rats fed with a standard diet (STD) or cafeteria diet (CD) receiving the dry extract from C. ecalyculata at 500, 1000, and $2000 \mathrm{mg} / \mathrm{kg}$ for 40 days. Furthermore, it evaluated the slimming effect on diet-induced obese rats by the treatment with the same doses for 30 days. The bodyweight of the rats, as well as the intake of food, was measured. Blood samples were collected to determine the liver function (albumin, alanine transaminase (ALT), alkaline phosphatase (ALP), glucose), renal function (urea and creatinine), and lipid profile (cholesterol, triglycerides).

Results. The genotoxic effect in peripheral blood was assessed through the comet assay. A lower C. ecalyculata dose significantly prevented the weight gain in rats fed with STD and CD and decreased body weight and intake food of obese rats. The biochemical parameters were not altered, except to increase the serum albumin. Only the higher dose induced DNA damage when evaluated in rats fed with CD in the slimming evaluation model used.

Conclusion. These results reinforce the extract as an anti-obesity and slimming supplement.
\end{abstract}

Keywords: comet assay, Cordia ecalyculata, hepatic profile, obesity

\section{INTRODUCTION}

According to the World Health Organization (WHO, 2020), overweight and obesity are linked to deaths worldwide. Furthermore, overweight and obesity, as well as their related noncommunicable diseases, are largely preventable. Herbal use is associated with health promotion (Wang et al., 2014), therefore many people use herbal medicines for weigh loss (Yun, 2010). This fact makes this kind of supplements very popular and commonly used worldwide since it leads to less or no side effects when compared to traditional pharmacological treatments (Hasani-Ranjbar et al., 2013). 
The main substances found in plants of the Boraginaceae family are alkaloids, quinones, naphthoquinones, saponins, tannins, phenolic acids, allantoins, mucilages, polysaccharides, flavonoids, cyclitols, and fatty acids of therapeutic and nutritional interest, such as gamma-linolenic acid (Velasco and Goffman, 1999). In this sense, the extract from the Brazilian plant belonging to the Boraginaceae family Cordia ecalyculata Vell. (synonym C. salicifolia Cham.), popularly known as "porangaba", "buggy tea", or "coffee bush" shows diuretic activity, leading to appetite suppression and weight reduction (Araldi et al., 2014; Menghini et al., 2008), as well as hypolipidemic effects (Siqueira et al., 2006). Phytochemical investigation on leaf extract of $C$. ecalyculata demonstrates high concentrations of caffeine, potassium, allantoic acid, and allantoin (Menghini et al., 2008). Furthermore, according to Volp et al. (2008), C. ecalyculata is rich in tannins and anthocyanins, which have antioxidant properties that can modulate the expression of adipokines and prevent fat accumulation.

Given that $C$. ecalyculata has been ethnopharmacologically referenced as an alternative treatment for obesity and has the pharmacological potential for the development of phytotherapeutic medicines, this study aimed to evaluate the anti-obesity and slimming effects in diet-induced obese rats. In addition, liver and kidney biochemical parameters were evaluated, as well as the genotoxic effects in the peripheral blood of animals treated sub chronically with the extract of $C$. ecalyculata.

\section{METHODS}

\section{Animals}

Ninety-six Wistar albino male rats aged 8-10 weeks old and weighing around 200-250 g from the Vivarium of Lutheran University of Brazil (ULBRA) were housed four per cage under $12-12 \mathrm{~h}$ daylight cycle and $23 \pm 2^{\circ} \mathrm{C}$ temperature. The experimental protocol was approved by the Ethics Committee on Animal Use at ULBRA (under protocol 2011-42P) and animal care was taken according to the guidelines as indicated in the recommendations of the National Institutes of Health Guide for the care and use of laboratory animals.

\section{Collection of plant material}

The dry extract of the leaves and stems of C. ecalyculata in powder form obtained from maceration was purchased from a raw material distributor in the state of Rio Grande do Sul (Embrafarma), Brazil, without additives. The test substance was presented in a $500 \mathrm{~g}$ package, and closed with a certification seal and a quality guarantee. The phytochemical analysis label, evaluated by the manufacturer, showed the presence of caffeine, allantoin, and tannins present.

\section{Experimental protocols}

Firstly, the animals were divided into two groups: Standard diet (STD) or Cafeteria diet (CD). Cafeteria diet was chosen because according to Buyukdere et al. (2019), it showed more pronounced obesity when compared to a high-fat diet in young male rats. In the current study, the STD was composed of the dry pellet Nuvilab CR® (Quimtia, Paraná, Brazil) containing crude protein (22 to $22.5 \%$ ), lipids (4.4\%), and carbohydrates (53 to $55 \%$ ), totaling $295 \mathrm{kcal} / 100 \mathrm{~g}$. The proposed CD includes supplementation with hypercaloric foods, and the average energy composition was $9 \%$ protein, $31.5 \%$ carbohydrates, and $60 \%$ lipids, adding $340 \mathrm{kcal}$ in 100 g. Cafeteria diet was prepared using (Jindal et al., 2011): a - bread (25 g) + condensed milk (25 g), $\mathrm{b}$ - chocolate biscuits $(25 \mathrm{~g})+$ potato chips $(25 \mathrm{~g}), \mathrm{c}-$ potato chips $(25 \mathrm{~g})+$ rice polish $(25 \mathrm{~g})$. These supplementations were offered along with STD for 3 days, in a sequence of $a, b$, and $c$ in rotation, for a total period of 30 days or 70 days, depending on the evaluation model. The animals received water ad libitum.

For the experiment, the test substance was homogenized in saline plus $0.05 \%$ carboxymethylcellulose and administered orally (via gavage) to the animals. Control animals received only carboxymethylcellulose $(0.05 \%)$. The doses used in this study were based on the results of Caparroz-Assef et al. (2008) and Dias (2004) who showed no mortality and acute toxicity of the hydroethanolic extract of the leaves of C. ecalyculata $(5000 \mathrm{mg} / \mathrm{kg})$ when it was administered for 15 days in male and female Wistar rats. Thus, the chosen doses were $500 \mathrm{mg} / \mathrm{kg}, 1000 \mathrm{mg} / \mathrm{kg}$, and 2000 $\mathrm{mg} / \mathrm{kg}$. To evaluate the effect of $C$. ecalyculata as an anti-obesity supplement, the animals were fed for 40 days with STD and CD together with the daily administration of the test substance in three different doses. To evaluate the effect on slimming, after 40 days from the beginning of the STD or CD feeding, the animals then maintained their diet for another 30 days plus daily treatment with the dry extract from $C$. ecalyculata 


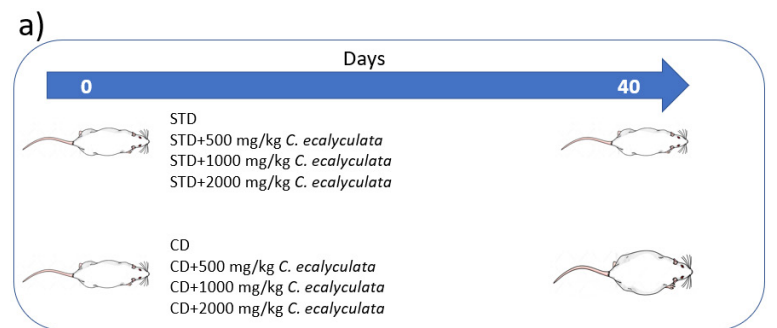

b)

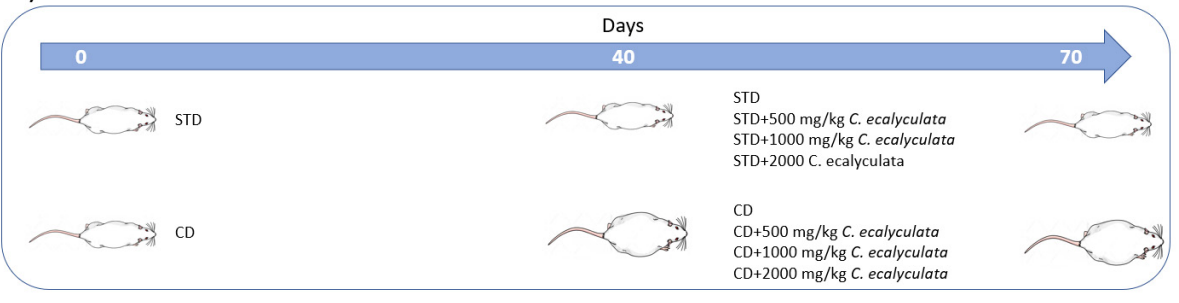

Fig. 1. Experimental design. Evaluation of dry extract of C. ecalyculata as anti-obesity (a) and slimming (b): STD - standard diet, CD - cafeteria diet. Each group was formed by 6 animals $(n=6)$

in the same three different dosages (Fig. 1). The animals were weighed at the beginning and end of the study. Each experimental group was formed by 6 animals $(n=6)$ and physical activity status was not assessed.

\section{Measurement of food intake}

The food intake of each animal was determined initially and then every week thereafter by measuring the difference between the pre-weighed pellets and the weight of the food that remained after 24 hours.

\section{Biochemical parameters}

At the end of the experimental protocols, the rats were euthanized by an isoflurane overdose. Blood samples were collected in a Vacutainer $\AA$ tube with EDTA to determine the liver function (albumin, alanine transaminase (ALT), alkaline phosphatase (ALP), glucose), renal function (urea and creatinine), and lipid profile (cholesterol, triglycerides).

\section{Genotoxicity assay}

Peripheral blood was used to perform the alkaline comet assay, as described by Tice et al. (2000), with minor modifications. As a positive control hydrogen peroxide $(0.25 \mathrm{mM}$ solution) was applied to slides for $5 \mathrm{~min}$, at a $4^{\circ} \mathrm{C}$ temperature. The extent of DNA damage was determined by classifying comets into five categories, based on the length of DNA migration and/or of the perceived relative proportion of the DNA in the tail to the size of the head (nucleus). The categories were zero, which represented undamaged cells (comets with no tail), and categories 1-4 that represented increasing relative tail intensities and smaller head sizes. The parameter used to evaluate DNA damage was the damage index (DI) and damage frequency (DF). The DI of a group could range from zero (completely undamaged $=100$ cells $\times 0$ ) to 400 (maximum damage $=100$ cells $\times 4)$. The DF was calculated based on the number of cells with a tail versus those without a tail.

\section{Statistical analyses}

The data were expressed as mean \pm standard deviation. The statistical analyses were carried out by a One-Way Analysis of Variance (ANOVA), followed by the post hoc test or Kruskal Wallis test (GraphPad Prism 5.0, USA). In all comparisons, $p \leq 0.05$ was considered an indicator of statistical significance.

\section{RESULTS}

\section{Anti-obesity effects of $C$. ecalyculata}

Animals that received STD or CD plus C. ecalyculata $500 \mathrm{mg} / \mathrm{kg}$ for 40 days, showed a significant decrease in weight gain. Curiously, the higher dose did not show significant effects. Furthermore, the intermediate dose in the animals fed with STD and treated 
Table 1. Anti-obesity effects of dry extract of C. ecalyculata p.o. for 40 days in the bodyweight of animals under standard diet (STD) or cafeteria diet (CD)

\begin{tabular}{ll}
\hline \multicolumn{1}{c}{ Group } & Mean $\pm \mathrm{SD}, \%$ \\
\hline STD & $29.9 \pm 8.7$ \\
STD $500 \mathrm{mg} / \mathrm{kg} \mathrm{C.} \mathrm{ecalyculata}$ & $11.1 \pm 6.6^{*}$ \\
STD $2000 \mathrm{mg} / \mathrm{kg}$ C. ecalyculata & $25.9 \pm 5.9$ \\
CD & $50.9 \pm 9.7$ \\
CD $500 \mathrm{mg} / \mathrm{kg} \mathrm{C.} \mathrm{ecalyculata}$ & $24.1 \pm 4.2^{* *}$ \\
CD $1000 \mathrm{mg} / \mathrm{kg} \mathrm{C.} \mathrm{ecalyculata}$ & $39.0 \pm 6.8$ \\
CD $2000 \mathrm{mg} / \mathrm{kg}$ C. ecalyculata & $36.6 \pm 6.8$ \\
\hline
\end{tabular}

$n=6$ animals per group.

${ }^{*} p<0.001$ when compared to the STD group. ${ }^{* *} p<0.001$ when compared to the CD group.

with C. ecalyculata $1000 \mathrm{mg} / \mathrm{kg}$ presented a high SD, becoming an inconclusive result (data not shown). Related to animals fed with $\mathrm{CD}$, the lower dose also was significantly effective in preventing weight gain (Table 1).

\section{Slimming effects of $C$. ecalyculata}

A significant decrease in weight after the treatment with C. ecalyculata $500 \mathrm{mg} / \mathrm{kg}$ for 30 days was observed in rats fed with STD. However, in animals fed with $\mathrm{CD}$, the loss of weight was observed in all groups treated with $C$. ecalyculata. The effect in rats fed with STD and treated with C. ecalyculata $500 \mathrm{mg} / \mathrm{kg}$ for 30 days was significant compared to other doses. On $\mathrm{CD}$-animals, it was possible to observe the same pattern of effect, although the intermediate and higher doses showed smaller significant effects (Table 2).

\section{Effect of $C$. ecalyculata on calorie intake}

The C. ecalyculata at $500 \mathrm{mg} / \mathrm{kg}$ treatment was able to significantly reduce the intake calories of rats under STD and CD in the anti-obesity evaluation. Furthermore, the same result can be observed in relation to the slimming evaluation (Table 3 ).

\section{Biochemical parameters}

Among the biochemical parameters evaluated, this study showed that albumin was significantly elevated
Table 2. Slimming effects of dry extract of $C$. ecalyculata p.o. for 30 days in the bodyweight of animals under standard diet (STD) or diet-induced obese rats

\begin{tabular}{ll}
\hline \multicolumn{1}{c}{ Group } & Mean $\pm \mathrm{SD}, \%$ \\
\hline STD & $6.5 \pm 5.1$ \\
STD $500 \mathrm{mg} / \mathrm{kg} \mathrm{C.} \mathrm{ecalyculata}$ & $-4.7 \pm 5.6^{*}$ \\
STD $1000 \mathrm{mg} / \mathrm{kg} \mathrm{C.} \mathrm{ecalyculata}$ & $2.5 \pm 4.3$ \\
STD $2000 \mathrm{mg} / \mathrm{kg}$ C. ecalyculata & $3.7 \pm 14.0$ \\
CD & $4.6 \pm 1.4$ \\
CD $500 \mathrm{mg} / \mathrm{kg} \mathrm{C.} \mathrm{ecalyculata}$ & $-7.3 \pm 6.3^{* *}$ \\
CD $1000 \mathrm{mg} / \mathrm{kg} \mathrm{C.} \mathrm{ecalyculata}$ & $-1.9 \pm 4.5^{* * *}$ \\
CD $2000 \mathrm{mg} / \mathrm{kg} \mathrm{C.} \mathrm{ecalyculata}$ & $-2.0 \pm 4.7^{* * *}$ \\
\hline
\end{tabular}

$n=6$ animals per group. $\mathrm{CD}-$ cafeteria diet.

Negative results mean a decrease in the body weight of the animals. ${ }^{*} p<0.001$ compared to the STD group. ${ }^{* *} p<0.001$ and ${ }^{* * *} p<0.05$ compared to the $\mathrm{CD}$ group.

Table 3. Effects of C. ecalyculata p.o. for 40 days in rats under standard diet (STD) or cafeteria diet (CD) (anti-obesity) and 30 days in obese animals under STD or CD (slimming) in the calories intake

\begin{tabular}{lcc}
\hline \multicolumn{1}{c}{ Group } & Anti-obesity & Slimming \\
\hline STD & 2709 & 2492 \\
& \pm 94.9 & \pm 38.6 \\
STD $500 \mathrm{mg} / \mathrm{kg} \mathrm{C.} \mathrm{ecalyculata}$ & 2110 & 2078 \\
& $\pm 94.6^{*}$ & $\pm 139.7^{*}$ \\
STD $1000 \mathrm{mg} / \mathrm{kg}$ C. ecalyculata & 2039 & 2409 \\
& $\pm 156.2^{*}$ & \pm 88.1 \\
STD $2000 \mathrm{mg} / \mathrm{kg}$ C. ecalyculata & 2256 & 2223 \\
& \pm 142.0 & \pm 85.27 \\
CD & 2854 & 2734 \\
& \pm 79.4 & \pm 133.2 \\
CD $500 \mathrm{mg} / \mathrm{kg}$ C. ecalyculata & 2284 & 2031 \\
& $\pm 165.7^{* * *}$ & $\pm 53.55^{* *}$ \\
$\mathrm{CD} 1000 \mathrm{mg} / \mathrm{kg}$ C. ecalyculata & 2419 & 2120 \\
& \pm 148.6 & $\pm 90.7^{* * *}$ \\
$\mathrm{CD} 2000 \mathrm{mg} / \mathrm{kg}$ C. ecalyculata & 2318 & 2243 \\
& \pm 140.8 & \pm 176.1 \\
\hline
\end{tabular}

$n=6$ animals per group.

Data expressed as mean \pm SD of energy intake for a group of six rats in kcal/week. ${ }^{*} p<0.05$ when compared to the STD group and ${ }^{* *} p<0.001 .{ }^{* * *} p<0.05$ when compared to the CD group. 
in groups fed with STD for 40 days and daily treated with $C$. ecalyculata $500 \mathrm{mg} / \mathrm{kg}(p<0.05), 1000$ and $2000 \mathrm{mg} / \mathrm{kg}(p<0.001)$ for another 30 days (Table 4$)$. Furthermore, the rats receiving $\mathrm{CD}$ and treated with 1000 and $2000 \mathrm{mg} / \mathrm{kg}$ of C. ecalyculata also showed albumin and glucose increases, although insignificant values.

The other biochemical parameters evaluated from the C. ecalyculata treated groups did not demonstrate any significant values compared to their respective control groups, except for a significant increase of ALP in an anti-obesity group fed with STD and treated with $1000 \mathrm{mg} / \mathrm{kg}$ (Table 4). On the other hand, when the obese-induced animals were treated with C. ecalyculata, only the group treated with a $1000 \mathrm{mg} / \mathrm{kg}$ dose showed a significant increase in ALP.

\section{Genotoxic effects}

Regarding anti-obesity evaluation, DI and DF values in groups treated with $C$. ecalyculata were similar compared to the respective control groups, except for a significantly decreased DF value observed in STD $500 \mathrm{mg} / \mathrm{kg}$. However, there was an increase in DI and $\mathrm{DF}$ values in the group fed with $\mathrm{CD}$ and treated with $2000 \mathrm{mg} / \mathrm{kg}$ for 30 days, suggesting induction of DNA damage in the highest dose (Table 5).

\section{DISCUSSION}

C. ecalyculata is marketed as an appetite reducer (Alexandre et al., 2018). According to Assonuma (2009), this plant contains phytochemical constituents of alkaloids like caffeine, allantoins, and allantoic acid,

Table 4. Biochemical effects of dry extract of $C$. ecalyculata p.o. for 40 days in rats under standard diet or cafeteria diet (anti-obesity) and 30 days in animals under standard diet or diet-induced obese rats (slimming)

\begin{tabular}{|c|c|c|c|c|c|c|c|c|c|}
\hline Parameter & Evaluation & STD & $\begin{array}{c}\text { STD } \\
500 \mathrm{mg} / \mathrm{kg} \\
\text { C. ecalyculata }\end{array}$ & $\begin{array}{c}\text { STD } \\
1000 \mathrm{mg} / \mathrm{kg} \\
\text { C. ecalyculata }\end{array}$ & $\begin{array}{c}\text { STD } \\
2000 \mathrm{mg} / \mathrm{kg} \\
\text { C. ecalyculata }\end{array}$ & $\mathrm{CD}$ & $\begin{array}{c}\text { CD } \\
500 \mathrm{mg} / \mathrm{kg} \\
\text { C. ecalyculatc }\end{array}$ & $\begin{array}{c}\text { CD } \\
1000 \mathrm{mg} / \mathrm{kg} \\
\text { C. ecalyculata }\end{array}$ & $\begin{array}{c}\text { CD } \\
2000 \mathrm{mg} / \mathrm{kg} \\
\text { C. ecalyculata }\end{array}$ \\
\hline \multirow[t]{2}{*}{ Albumin } & anti-obesity & $1.9 \pm 0.4$ & $2.7 \pm 0.9$ & $2.4 \pm 0.8$ & $1.9 \pm 0.3$ & $2.4 \pm 0.6$ & $2.0 \pm 0.5$ & $2.0 \pm 0.5$ & $2.5 \pm 0.8$ \\
\hline & slimming & $2.1 \pm 0.5$ & $3.5 \pm 0.4^{*}$ & $4.0 \pm 0.3^{* *}$ & $3.2 \pm 0.7^{* *}$ & $2.9 \pm 0.6$ & $4.2 \pm 0.9$ & $4.7 \pm 0.6^{* * *}$ & $6.0 \pm 0.9^{* * *}$ \\
\hline \multirow[t]{2}{*}{ ALT } & anti-obesity & $30.4 \pm 10.0$ & $33.6 \pm 5.2$ & $52.5 \pm 13.3$ & $34.4 \pm 12.7$ & $43.2 \pm 16.9$ & $35.3 \pm 8.2$ & $49.1 \pm 26.7$ & $33.9 \pm 10.2$ \\
\hline & slimming & $42.5 \pm 5.4$ & $42.6 \pm 8.9$ & $40.0 \pm 3.9$ & $43.8 \pm 1.6$ & $44.7 \pm 6.8$ & $34.0 \pm 8.1$ & $28.7 \pm 9.8$ & $38.8 \pm 10.1$ \\
\hline \multirow[t]{2}{*}{ ALP } & anti-obesity & $94.7 \pm 14.7$ & $124.6 \pm 45.5$ & $220.2 \pm 46.5^{* *}$ & $108.3 \pm 48.1$ & $111.7 \pm 21.5$ & $81.5 \pm 20.7$ & $145.7 \pm 31.6$ & $134.7 \pm 30.8$ \\
\hline & slimming & $110.8 \pm 22.2$ & $116.1 \pm 20.3$ & $83.8 \pm 45.9$ & $148.9 \pm 61.2$ & $106.7 \pm 21.7$ & $121.4 \pm 28.3$ & $191.2 \pm 150.5$ & $132.6 \pm 53.6$ \\
\hline \multirow[t]{2}{*}{ Glucose } & anti-obesity & $58.8 \pm 20.9$ & $75.8 \pm 9.0$ & $63.4 \pm 16.1$ & $61.6 \pm 17.0$ & $66.7 \pm 16.7$ & $82.8 \pm 17.1$ & $87.7 \pm 27.2$ & $71.7 \pm 34.5$ \\
\hline & slimming & $140.6 \pm 28.8$ & $134.6 \pm 34.6$ & $129.5 \pm 29.4$ & $121.9 \pm 26.7$ & $163.7 \pm 7.8$ & $163.8 \pm 35.1$ & $210.7 \pm 28.8$ & $179.1 \pm 28.9$ \\
\hline \multirow[t]{2}{*}{ Urea } & anti-obesity & $43.2 \pm 3.8$ & $46.5 \pm 8.6$ & $42.3 \pm 5.5$ & $41.6 \pm 8.7$ & $38.9 \pm 2.4$ & $40.3 \pm 5.3$ & $39.1 \pm 3.3$ & $49.5 \pm 12.5$ \\
\hline & slimming & $55.4 \pm 9.5$ & $51.0 \pm 8.9$ & $54.2 \pm 17.0$ & $74.3 \pm 15.2$ & $44.2 \pm 2.7$ & $50.1 \pm 8.1$ & $52.1 \pm 7.9$ & $59.4 \pm 5.6$ \\
\hline \multirow[t]{2}{*}{ Creatinine } & anti-obesity & $0.6 \pm 0$ & $0.6 \pm 0.1$ & $0.6 \pm 0$ & $0.5 \pm 0.1$ & $0.5 \pm 0.1$ & $0.6 \pm 0.2$ & $0.6 \pm 0.1$ & $0.7 \pm 0.2$ \\
\hline & slimming & $0.7 \pm 0.1$ & $0.9 \pm 0.2$ & $0.7 \pm 0.2$ & $0.8 \pm 0.2$ & $0.7 \pm 0.3$ & $0.8 \pm 0.1$ & $0.8 \pm 0.1$ & $0.6 \pm 0.1$ \\
\hline \multirow{2}{*}{$\begin{array}{l}\text { Total } \\
\text { cholesterol }\end{array}$} & anti-obesity & $97.4 \pm 57.8$ & $104.6 \pm 27.4$ & $157.1 \pm 41.4$ & $89 \pm 28.7$ & $67.2 \pm 15.1$ & $87.8 \pm 18.2$ & $77.2 \pm 20.4$ & $135.9 \pm 48.3$ \\
\hline & slimming & $86.6 \pm 8.2$ & $116.3 \pm 21.5$ & $101.5 \pm 12.8$ & $92.5 \pm 24.0$ & $98.3 \pm 22.5$ & $114.6 \pm 18.9$ & $96.3 \pm 18.0$ & $129.9 \pm 35.3$ \\
\hline \multirow{2}{*}{$\begin{array}{l}\text { Triglyce- } \\
\text { rides }\end{array}$} & anti-obesity & $64.9 \pm 52.0$ & $70.0 \pm 42.5$ & $52.7 \pm 44.6$ & $37.1 \pm 10.5$ & $44.4 \pm 12.0$ & $116.5 \pm 20.3$ & $80.1 \pm 29.9$ & $49.4 \pm 17.2$ \\
\hline & slimming & $50.7 \pm 10.5$ & $70.5 \pm 27.0$ & $64.6 \pm 15.9$ & $59.6 \pm 22.0$ & $92.5 \pm 52.7$ & $52.3 \pm 11.6$ & $60.0 \pm 12.5$ & $79.8 \pm 16.7$ \\
\hline
\end{tabular}

$n=6$ animals per group. STD - standard diet, $\mathrm{CD}$ - cafeteria diet. Data expressed as mean \pm SD.

${ }^{*} p<0.05$ and ${ }^{* *} p<0.01$ when compared to the STD group. ${ }^{* * *} p<0.01$ when compared to the CD group. 
Nunes, L. F., Techera Antunes, F. T., de Souza, A. H., de Souza Teixeira, V., de Fátima Wiillandm, E., Nascimento Picada, J., da Silva Brum, L. F. (2022). Anti-obesity, slimming, biochemical and genotoxic effects of Cordia ecalyculata in diet-induced obese rats. Acta Sci. Pol. Technol. Aliment., 21(1), 101-109. http://dx.doi.org/10.17306/J.AFS.2022.0998

Table 5. Genotoxic effects of $C$. ecalyculata p.o. for 40 days in rats under standard diet or cafeteria diet (anti-obesity) and 30 days in animals under standard diet or diet-induced obese rats (slimming)

\begin{tabular}{|c|c|c|c|c|c|c|c|c|c|}
\hline $\begin{array}{l}\text { Evalua- } \\
\text { tion }\end{array}$ & Evaluation & STD & $\begin{array}{c}\text { STD } \\
500 \mathrm{mg} / \mathrm{kg} \\
\text { C. ecalyculata }\end{array}$ & $\begin{array}{c}\text { STD } \\
1000 \mathrm{mg} / \mathrm{kg} \\
\text { C. ecalyculata }\end{array}$ & $\begin{array}{c}\text { STD } \\
2000 \mathrm{mg} / \mathrm{kg} \\
\text { C. ecalyculata }\end{array}$ & $\mathrm{CD}$ & $\begin{array}{c}\mathrm{CD} \\
500 \mathrm{mg} / \mathrm{kg} \\
\text { C. ecalyculata }\end{array}$ & $\begin{array}{c}\text { CD } \\
1000 \mathrm{mg} / \mathrm{kg} \\
\text { C. ecalyculata }\end{array}$ & $\begin{array}{c}\mathrm{CD} \\
2000 \mathrm{mg} / \mathrm{kg} \\
\text { C. ecalyculata }\end{array}$ \\
\hline \multirow{2}{*}{$\begin{array}{l}\text { Anti- } \\
\text { obesity }\end{array}$} & DI & $56.8 \pm 25.9$ & $43.0 \pm 8.2$ & $84.8 \pm 37.5$ & $84.6 \pm 51.8$ & $53.6 \pm 35.9$ & $60.0 \pm 28.4$ & $35.8 \pm 4.6$ & $41.0 \pm 18.2$ \\
\hline & $\mathrm{DF}$ & $28.4 \pm 7.3$ & $18.2 \pm 3.6^{*}$ & $39.2 \pm 20.1$ & $39.0 \pm 16.1$ & $24.2 \pm 15.9$ & $36.2 \pm 15.1$ & $17.6 \pm 3.4$ & $21.0 \pm 11.7$ \\
\hline \multirow[t]{2}{*}{ Slimming } & DI & $32.8 \pm 25.5$ & $25.4 \pm 7.9$ & $27.8 \pm 24.9$ & $17.6 \pm 7.1$ & $13.2 \pm 4.4$ & $15.4 \pm 8.7$ & $26.2 \pm 18.5$ & $91.6 \pm 32.3^{* * *}$ \\
\hline & DF & $23.0 \pm 14.6$ & $13.4 \pm 3.9$ & $12.0 \pm 7.4$ & $7.4 \pm 1.8$ & $12.0 \pm 3.1$ & $8.4 \pm 4.1$ & $15.0 \pm 7.9$ & $57.2 \pm 17.3^{* * *}$ \\
\hline
\end{tabular}

$n=6$ animals per group. STD - standard diet, CD - cafeteria diet, DI - damage index, DF - damage frequency.

Data expressed as mean $\pm \mathrm{SD},{ }^{*} p<0.05$ when compared to the STD group. ${ }^{* *} p<0.01$ when compared to the CD group.

glycosides, tannins, and flavonoids. In this sense, extracts from plants showing those compounds have been proven to regulate adipogenesis (Wang et al., 2020). No data mentions the usual doses in the clinical field, therefore, no scientific basis is given to justify the suggested doses in the drugstores which market the extract (125-300 mg twice a day) (Pelizza, 2010). Due to the scarcity of scientific evidence on therapeutic effects of the dry extract of $C$. ecalyculata, this study evaluated the anti-obesity and slimming effects in rats fed with STD or CD and treated orally with the extract, since this plant is administered using this via in human. Even so, it is needed to point out that the exact mechanism of action is unknown, as well as whether it can be directly transferred to humans.

The lower dose $(500 \mathrm{mg} / \mathrm{kg})$ of C. ecalyculata administrated for 40 days significantly prevented the weight gain in rats being fed with STD or CD. Furthermore, using the same dosage administered for 30 days, rats fed with STD and rats fed with CD became thin. Conversely, in previous studies by Santos (2014) and Colli et al. (2016), a hydroethanolic extract of C. ecalyculata at 20,100 , and $400 \mathrm{mg} / \mathrm{kg}$ for 60 consecutive days orally did not show a reduction in body weight. In addition, Caparroz-Assef et al. (2008) have shown that the daily oral administration of a $C$. ecalyculata aqueous extract at $20,100,200$, and $400 \mathrm{mg} / \mathrm{kg}$ for 90 days did not cause changes in body weight gain. Also, da Silva et al. (2010) have observed that the oral treatment with the crude extract from $C$. ecalyculata $2000 \mathrm{mg} / \mathrm{kg}$ for 15 days did not reduce body weight gain or the amount of food consumed by Swiss mice. Siqueira et al. (2006) investigated the dried, powdered leaves of C. ecalyculata $(20 \mathrm{mg} / \mathrm{kg})$ administered by gavage for 13 days and did not find anti-obesity, appetite suppressant, and diuretic effects, but the hypolipidemic effect in normal and alloxan-diabetic rats was observed. However, corroborating in part with the currrent results, Araldi et al. (2014) found weight reduction in female Swiss mice in groups receiving 150 and $300 \mathrm{mg} / \mathrm{kg} \mathrm{C.} \mathrm{ecalyculata} \mathrm{orally} \mathrm{for} 7$ consecutive days, receiving a standard diet.

In this study, the biochemical parameters evaluated were not altered, except for the serum albumin which showed an increase when both the anti-obesity and slimming evaluations were performed, mainly in rats fed with STD and CD receiving C. ecalyculata at 1000 and $2000 \mathrm{mg} / \mathrm{kg}$. The serum albumin levels increase is linked to hepatic injury, and it is commonly an increase in the serum ALT and AST levels (Brisotti et al., 2000; Hamid et al., 2012; Jackson et al., 2008). When the anti-obesity effects were evaluated in rats fed with STD treated with $1000 \mathrm{mg} / \mathrm{kg}$, the serum ALP levels were increased. According to Xu et al. (2002), little is known about the role of ALP in liver diseases. However, the ALP results found here are not able to suggest hepatotoxicity caused by the dry extract of C. ecalyculata, and further studies to measure other biomarkers and analyzing the liver histopathology are needed. Cardozo et al. (2008) found a reduction in serum total cholesterol in mice fed with STD and treated orally with a $C$. ecalyculata dry extract $(100 \mathrm{mg} / \mathrm{kg}$ for 15 days), as well as a reduction in the serum triglyceride in animals under hyperlipidemia diet plus extract. Here, total cholesterol and triglyceride values remained at normal levels in all groups studied, 
indicating that the extract was not able to alter the lipid profile. Therefore, looking at the biochemistry panels, there is no dyslipidemia present and no obese animals showed alterations in glucose levels, showing a little evidence that the rats had obesity that could be alleviated in the slimming study.

Caparroz-Assef et al. (2008) revealed that the daily oral administration of an aqueous extract $(20,100$, 200 , and $400 \mathrm{mg} / \mathrm{kg}$ ) for 90 days did not cause changes in organ weight, hematological, and biochemical parameters of the animals, that is, it did not cause toxicity under chronic use. However, the reproductive toxic potential of different doses of the extract of C. ecalyculata in adult rats showed that the weight of the testicles, seminal glands, and prostate were not affected by treatments, but there was an increase in the epididymis weight at a dose of $400 \mathrm{mg} / \mathrm{kg}$ of the extract administered for 60 consecutive days. Besides, at all doses, the testicles and epididymis showed histopathological changes with an increase in the percentage of abnormal gametes and a decrease in fertility of animals (Colli et al., 2016; Santos, 2014).

Regarding genotoxic evaluation using comet assay, only the higher dose $(2000 \mathrm{mg} / \mathrm{kg})$ was able to increase DNA damage after 30 days of administration in rats fed with $\mathrm{CD}$ (Table 4). Interestingly, the extract did not show genotoxic effects in rats fed with STD, suggesting an influence of the diet on these results. It is known that some diets might disturb genomic stability mainly by altering the cellular redox state (Minihane et al., 2015; Włodarczyk and Nowicka, 2019). Thus, the extract induced DNA damage in rats fed with $\mathrm{CD}$, but not in rats fed with STD, likely because CD impaired DNA repair, decreasing the genomic stability and favoring the induction of DNA damage by chemical substances in the extract. Da Silva et al. (2010) have shown that a C. ecalyculata crude extract at 500, 1000 , and $2000 \mathrm{mg} / \mathrm{kg}$ did not increase DNA damage in blood and micronucleus frequency in bone marrow polychromatic erythrocytes of male Swiss mice, $24 \mathrm{~h}$ after the treatment. Also, Araldi et al. (2014) did not observe clastogenic activity in bone marrow polychromatic erythrocytes of mice treated for 7 consecutive days in dose up to $500 \mathrm{mg} / \mathrm{kg}$, suggesting that the extract did not induce genotoxic and mutagenic activities. In those studies, a standard diet was used, corroborating the lack of genotoxic effects of the extract in rats fed with SDT. In the anti-obesity evaluation, the extract was not able to induce DNA damage, even in rats fed with $C D$. In this case, the extract probably avoided the increase of genomic instability that could be caused by the $C D$, since the treatments started simultaneously with the diets.

Taken together, the results demonstrated that the lower dose of the dry extract of $C$. ecalyculata has anti-obesity and slimming effects in both STD and CD groups, without inducing DNA damage or altering biochemical parameters (Fig. 2). The reduction in the

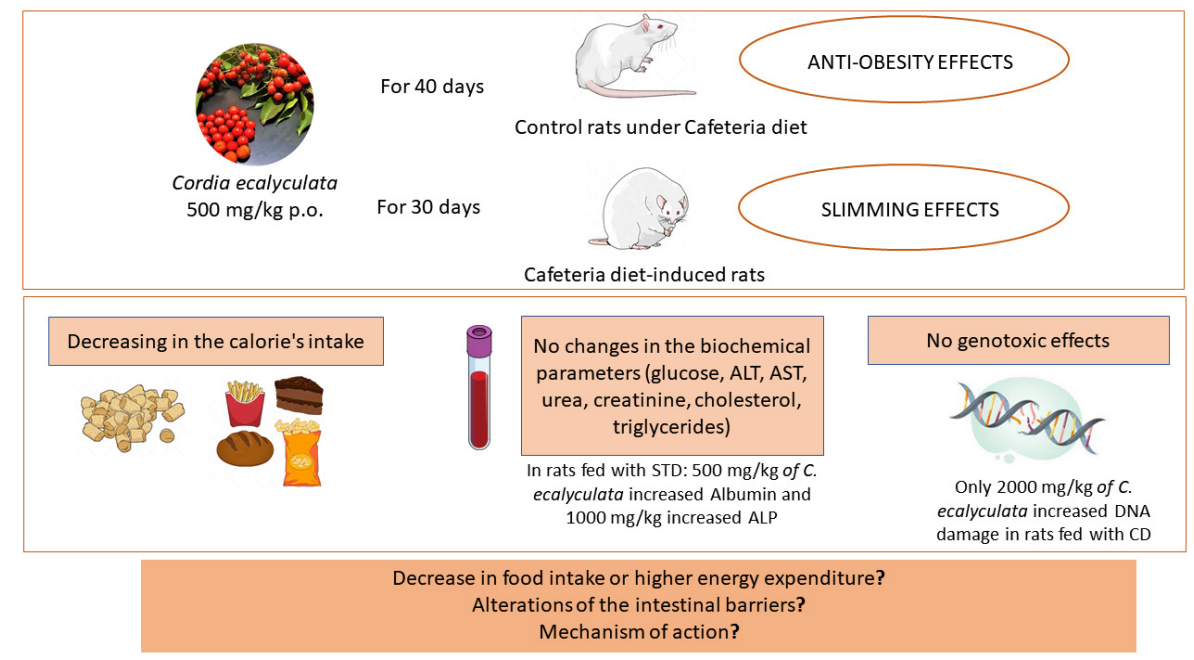

Fig. 2. Graphical conclusion 
final body weight could be due to a decrease in food intake or higher energy expenditure (Perumal et al., 2021), and it is in line with the present findings. Moreover, alterations of the intestinal barriers also could cause the inhibition of body weight gain (Karimi et al., 2015). These results indicate this plant is promising as an anti-obesity and slimming supplement, although more studies are needed to assess its safety and efficacy. Elucidation of its mechanism of action is also needed, which could be derivative from the phytochemical components of leaf extract of $C$. ecalyculata.

\section{REFERENCES}

Alexandre, K. P., Yasuda, F. S., Marques, L. C., Gonçalves, C. P., Veiga, R. S., Oliveira, S. M. L., Marcucci, M. C. (2018). Guaçatonga (Casearia sylvestris SW) e porangaba (Cordia salicifolia ou Cordia ecalyculata Vell / Boraginaceae) possuem ação no emagrecimento? [Do Guaçatonga (Casearia sylvestris SW) and porangaba (Cordia salicifolia or Cordia ecalyculata Vell / Boraginaceae) have action on weight loss?]. Braz. J. Nat. Sci., 1, 3-15. http://dx.doi.org/10.31415/bjns.v1i3.34

Araldi, R. P., Rechiutti, B. M., Mendes, T. B., Ito, E. T., Souza, E. B. (2014). Mutagenic potential of Cordia ecalyculata alone and in association with Spirulina maxima for their evaluation as candidate anti-obesity drugs. Genet. Mol. Res., 13, 5207-5220. http://dx.doi. org/10.4238/2014.July.7.14

Assonuma, M. M. (2009). Determinação de alantoína e avaliação farmacológica de Cordia ecalyculata Vell. (chá de bugre) [Allantoin determination and pharmacological evaluation of Cordia ecalyculata Vell. (buggy tea)]. Master's thesis, Universidade Estadual Paulista, Sâo Paulo, Brasil.

Brisotti, J. L., Picinato, M. A. N. C., Franco, C. F. F., Gomes, M. C. J., Souza, M. E. J., Barion, A. P., Silva de Castro, O. Jr (2000). Efeito da deferoxamina na isquemia e reperfusão do fígado remanescente após ressecção hepática parcial [Effect of deferoxamine on ischemia and reperfusion of the remaining liver after partial liver resection]. Acta Cir. Bras., 15, 47-49. http://dx.doi.org/10.1590/ S0102-86502000000600014

Buyukdere, Y., Gulec, A., Akyol, A. (2019). Cafeteria diet increased adiposity in comparison to high fat diet in young male rats. PeerJ., 7. e6656. http://dx.doi.org/10.7717/ peerj. 6656

Caparroz-Assef, S. M., Grespan, R., Batista, R. C. F., Bersani-Amado, F. A., Baroni, S., Dantas, J. A., Cuman, R.
K. N., Bersani-Amado, C. A. (2008). Toxicity studies of Cordia salicifolia extract. Acta Sci. Health Sci., 27, 41-44.

Cardozo, S., de Bona, L. R., Braboza, L. T., Andreolla, H. F., Boeck, R., Vieira, V., ..., Tavares, R. G. (2008). Atividade hipolipidêmica do extrato de Cordia salicifolia em camundongos submetidos a dieta hiperlipidêmica [Hypolipidemic activity of Cordia salicifolia extract in mice on a hyperlipidemic diet]. Rev. AMRIGS, 52, 182-186.

Colli, L. G., dos Santos, M. C., Tambor, J., Camargo, C. C. (2016). The administration of hydroethanolic extract of Cordia ecalyculata Vell. at different doses promotes reproductive toxicity in adult male rats. J. Interdisc. Histopathol., 4, 93-98. http://dx.doi.org/10.5455/jihp.2016 0706103059

da Silva, C. J., Bastos, J. K., Takahashi, C. S. (2010). Evaluation of the genotoxic and cytotoxic effects of crude extracts of Cordia ecalyculata and Echinodorus grandiflorus. J. Ethnopharm., 127, 445-450. http://dx.doi. org/10.1016/j.jep.2009.10.015

Dias, T. G. (2004). Estudo farmacognóstico de porangaba (Cordia ecalyculata Vell. - Boraginaceae) e identificação de adulterações. Master's thesis. Faculdade de Ciências Farmacêuticas da Universidade de São Paulo, São Paulo, Brasil.

Hamid, K., Urmi, K. F., Kabir, M. S., Ullah, M. O., Choudhuri, M. S. K. (2012). Toxicological studies of Astavarga Kvatha Curna, an Ayurvedic formulation, on liver function parameters of rat plasma. Biol. Med., 4, 27-31.

Hasani-Ranjbar, S., Jouyandeh, Z., Abdollahi, M. (2013). A systematic review of anti-obesity medicinal plants an update. J. Diab. Metab. Disord., 12, 28-29. http:// dx.doi.org/10.1186/2251-6581-12-28

Jackson, E. R., Kilroy, C., Joslin, D. L., Schomaker, S. L., Pruimboom-Bress, I., Amacher, D. E. (2008). The early effects of short-term dexamethasone administration on hepatic and serum alanine aminotransferase in the rat. Drug Chem. Toxicol., 31, 427-445.

Jindal, V., Dhingra, D., Sharma, S., Parle, M., Harna, R. K. (2011). Hypolipidemic and weight reducing activity of the ethanolic extract of Tamarindus indica fruit pulp in cafeteria diet- and sulpiride-induced obese rats. J. Pharmacol. Pharmacother., 2, 80-84. http://dx.doi. org/10.4103/0976-500X.81896

Karimi, G., Sabran, M. R., Jamaluddin, R., Parvaneh, K., Mohtarrudin, N., Ahmad, Z., ..., Khodavandi, A. (2015). The anti-obesity effects of Lactobacillus casei strain Shirota versus Orlistat on high fat diet-induced obese rats. Food Nutr. Res., 59, 29273-29275. http://dx.doi. org/10.3402/fnr.v59.29273 
Nunes, L. F., Techera Antunes, F. T., de Souza, A. H., de Souza Teixeira, V., de Fátima Wiillandm, E., Nascimento Picada, J., da Silva Brum, L. F. (2022). Anti-obesity, slimming, biochemical and genotoxic effects of Cordia ecalyculata in diet-induced obese rats. Acta Sci. Pol. Technol. Aliment., 21(1), 101-109. http://dx.doi.org/10.17306/J.AFS.2022.0998

Menghini, L., Epifano, F., Leporini, L., Pagiotti, R., Tirillini, B. (2008). Phytochemical investigation on leaf extract of Cordia salicifolia Cham. J. Med. Food., 11, 193-194. http://dx.doi.org/10.1089/jmf.2007.583

Minihane, A. M., Vinoy, S., Russell, W. R., Baka, A., Roche, H. M., Tuohy, K. M., ..., Calder, C. (2015). Low-grade inflammation, diet composition and health: current research evidence and its translation. Br. J. Nutr., 2015. 114, 999-1012. http://dx.doi.org/10.1017/ S0007114515002093

Pelizza, M. C. (2010). Uso de Cereus sp. e Cordia ecalyculata Vell. como emagrecedores: uma revisão [The use of Cereus sp. an Cordia ecalyculata Vell. as slimming agentes: a review]. Pharmacy undergraduation. Master's thesis. Universidade Federal do Rio Grande do Sul, Porto Alegre, Brasil.

Perumal, K. V., Ja'afar, N. L., Mat Taib, C. N., Shafie, N. H., Bahari, H. (2021). Antiobesity activity of Elateriospermum tapos shell extract in obesity-induced Sprague dawley rats. Molecules, 26, 321-322. http://dx.doi. org $/ 10.3390 /$ molecules 26020321

Santos, M. C. (2014). Avaliação do potencial tóxico reprodutivo do extrato de Cordia ecalyculata Vell: em ratos Wistar [Evaluation of the toxic reproductive potential of Cordia ecalyculata Vell extract: in Wistar rats]. Master's thesis. Universidade Estadual Paulista Júlio de Mesquita Filho, São Paulo, Brasil.

Siqueira, V. L. D., Cortez, D. A. G., Oliveira, C. E., Nakamura, C. V., Bazotte, R. B. (2006). Pharmacological studies of Cordia salicifolia cham in normal and diabetic rats. Braz. Arch. Biol. Technol., 49, 215-218. http:// dx.doi.org/10.1590/S1516-89132006000300005

Tice, R. R., Agurell, E., Anderson, D., Burlinson, B., Hartmann, A., Kobayashi, H., ..., Sasaki, Y. F. (2000). Single cell gel/comet assay: guidelines for in vitro and in vivo genetic toxicology testing. Environ. Mol. Mutagen. 35, 206-221. http://dx.doi.org/10.1002/(sici)1098-2280(2000) 35:3<206::aid-em8>3.0.co;2-j

Velasco, L., Goffman, F. D. (1999). Chemotaxonomic significance of fatty acids and tocopherols in Boraginaceae. Phytochem., 1999, 52, 423-426. http://dx.doi. org/10.1016/S0031-9422(99)00203-4

Volp, A. C. P., Renhe, I. R. T., Barra, K., Stringueta, P. C. (2008). Flavonoids anthocyanins: characteristics and properties in nutrition and health. Rev. Bras. Nutr. Clin., 23(2), 141-149.

Wang, H. N., Xiang, J. Z., Qi, Z., Du, M. (2020). Plant extracts in prevention of obesity. Crit. Rev. Food Sci. Nutr., 1-14. http://dx.doi.org/10.1080/10408398.2020.1 852171

Wang, W., Russell, A., Yan, Y., (2014). Traditional Chinese medicine and new concepts of predictive, preventive and personalized medicine in diagnosis and treatment of suboptimal health. EPMA J., 5, 4-6. http://dx.doi. org/10.1186/1878-5085-5-4.

Włodarczyk, M., Nowicka, G. (2019). Obesity, DNA damage, and development of obesity-related diseases. Int. J. Mol. Sci., 20, 1146-1147. http://dx.doi.org/10.3390/ ijms20051146

WHO (2021). Obesity and overweight. Retrieved April $1^{\text {st }}$, 2021 from: https://www.who.int/news-room/fact-sheets/ detail/obesity-and-overweight

Xu, Q., Lu, Z., Zhang, X. (2002). A novel role of alkaline phosphatase in protection from immunological liver injury in mice. Liver, 22, 8-14.

Yun, J. W. (2010). Possible anti-obesity therapeutics from nature - a review. Phytochemistry, 71, 1625. 
